\title{
Structure and dynamics of mussel patches in tide- pools on a rocky shore in Nova Scotia, Canada
}

\author{
Heather L. Hunt* ${ }^{*}$ Robert E. Scheibling \\ Biology Department, Dalhousie University, Halifax, Nova Scotia, Canada B3H 4J1
}

\begin{abstract}
The distribution, size structure, and dynamics of mussel (Mytilus trossulus, $M$. edulis) patches in tidepools were studied on an exposed rocky shore near Halifax, Nova Scotia, Canada. The mussel patches were dynamic, frequently coalescing with one another or disappearing, but mean change in patch area did not vary significantly among seasons or years. Recolonization of areas from which patches were removed occurred slowly, usually by recruitment. Both established and recolonized patches were generally associated with macroalgae. Mussel patches were primarily composed of individuals $<5 \mathrm{~mm}$ in shell length (SL) which appeared to be very slow growing. The percentage of new recruits in a patch varied among pools and between years. Predation by the dogwhelk Nucella lapillus was a major cause of mussel mortality. The size distributions of live and dead mussels in the patches differed significantly: the frequency of dead mussels $<5 \mathrm{~mm}$ SL was less than that of live mussels, and the frequency of dead mussels 5 to $10 \mathrm{~mm}$ SL was greater than that of live mussels. Dead mussels (not killed by whelks) were more frequent in October 1992 than in June 1992, while no clear temporal patterns were found in the frequency of mussels killed by whelks.
\end{abstract}

KEY WORDS: Mussels - Patch dynamics - Tidepools - Recruitment - Predation Growth rate - Spatial distribution Rocky intertidal zone - Mytilus edulis $\cdot$ Mytilus trossulus

\section{INTRODUCTION}

Mussels are among the dominant occupiers of space in the intertidal zones of rocky shores. The demography of mussel populations on emergent substrata has been well studied (for review see Seed 1976, Seed \& Suchanek 1992), as have the effects of competition (Dayton 1971, Menge 1976, Lubchenco \& Menge 1978, McCook \& Chapman 1991), predation (Kitching et al. 1959, Dayton 1971, Paine 1974, 1976, Menge 1978, 1983, Robles 1987, Petraitis 1990) and physical disturbance (Dayton 1971, Paine \& Levin 1981) on the dynamics of these populations. Mussels are also a common component of tidepool communities (GossCustard et al. 1979, Dethier 1984, Huggett \& Griffiths 1986, Lawrence \& McClintock 1987, Kooistra et al. 1989), but little is known about their population structure and dynamics in these microhabitats. Previous studies have examined the physiology of mussels in tidepools, including their growth rates (Mossop 1921)

\footnotetext{
•E-mail: hlhunt@ac.dal.ca
}

and energetics (Clarke \& Griffiths 1990). However, ecological processes which influence assemblages of mussels in tidepools have not been studied, and these may differ considerably from processes operating on emergent substrata. For example, the mortality rate of mussels may be higher in tidepools where constant submergence increases the foraging time for predators such as whelks (Stickle et al. 1985, Burrows \& Hughes 19911.

On rocky shores along the Atlantic coast of Nova Scotia, Canada, the mussels Mytilus trossulus and $M$. edulis (hereafter Mytilus) co-occur in the mid to low intertidal and are distinguishable at small sizes only by electrophoretic techniques (Pedersen 1991). Mussels in tidepools tend to occur in small patches, whereas those on emergent substrata often form extensive beds. In this study, we examine spatial and temporal patterns in patch structure and dynamics of Mytilus in tidepools at an exposed site over $20 \mathrm{mo}$. These observations give insight into various physical and biological factors influencing the distribution and abundance of mussels in tidepools and provide a basis for comparison with mussel assemblages on emergent substrata. 


\section{MATERIALS AND METHODS}

This study was conducted in 5 tidepools in the mid to low intertidal zone at Cranberry Cove $\left(44^{\circ} 30^{\prime} \mathrm{N}\right.$, $63^{\circ} 56^{\prime}$ W), near Halifax, Nova Scotia, between October 1991 and June 1993. This shore is composed of granite platforms and outcrops and is exposed to southwesterly swells with wave heights of up to $10 \mathrm{~m}$ during fall and winter storms. The pools ranged from $1.6 \mathrm{~m}$ to $7.2 \mathrm{~m}$ in length, from 1.1 to $2.8 \mathrm{~m}$ in width, and from $0.3 \mathrm{~m}$ to $0.6 \mathrm{~m}$ in depth (Table 1 ). The average isolation time of the pools (i.e. the period between tidal recession and subsequent input) was 4 to $6 \mathrm{~h}$, based on repeated observations over the course of the study. The flushing time of the pools was measured in August 1993 as the time taken for a fluorescent red dye (Rhodamine B. Sigma Chemicals; initial conc. 1.8 to $6.7 \mathrm{mg}$ $\mathrm{I}^{-1}$ ), added at slack low tide, to become undetectable to a spectrophotometer (Perkin-Elner, Lambda 3B). All of the pools were flushed completely within 3 to $4.7 \mathrm{~h}$ after low tide (Table 1).

The spatial distribution of the Mytilus patches was measured in $0.01,0.04$, and $0.25 \mathrm{~m}^{2}$ quadrats that were haphazardly placed within pools in October 1991. The number of quadrats $(n)$ sampled at each spatial scale ranged from 4 to 24 . The spatial distribution of patches at each quadrat size was measured using Morisita's Index of Dispersion $\left(I_{\delta}\right)$ :

$$
I_{\delta}=\frac{\mathrm{n} \sum\left(x^{2}\right)-\sum x}{\left(\sum x\right)^{2}-\sum x}
$$

where $x$ equals the number of individuals per quadrat and $n$ the number of quadrats in a sample (Elliott 1971). The index equals 1 for a random distribution, is $>1$ for an aggregated distribution, and is $<1$ for a regular distribution. The test statistic $I_{\hat{\delta}}\left(\sum x-1\right)+\mathrm{n}-\sum x$ is applied to a $\chi^{2}$ distribution with $n-1$ degrees of freedom to determine significant departures $(\alpha=0.05)$ from a random distribution.

To measure change in Mytilus patch area over time, 20 discrete patches, $<200 \mathrm{~cm}^{2}$ in area, were selected in

Table 1. Physical characteristics of 5 tidepools in the mid and low intertidal zone at Cranberry Cove, Nova Scotia, Canada. Flushing time: number of hours required after low tide for the pool to be completely flushed with new sea water

\begin{tabular}{|ccccc|}
\hline Pool & $\begin{array}{c}\text { Maximum } \\
\text { depth (m) }\end{array}$ & $\begin{array}{c}\text { Length } \\
(\mathrm{m})\end{array}$ & $\begin{array}{c}\text { Width } \\
(\mathrm{m})\end{array}$ & $\begin{array}{c}\text { Flushing } \\
\text { time }(\mathrm{h})\end{array}$ \\
\hline 1 & 0.3 & 7.2 & 2.7 & 3.0 \\
2 & 0.6 & 6.6 & 1.7 & 4.7 \\
3 & 0.4 & 1.6 & 1.1 & 3.8 \\
4 & 0.5 & 5.7 & 2.8 & 3.0 \\
5 & 0.4 & 3.2 & 1.1 & 4.5 \\
\hline
\end{tabular}

each pool and sampled on 7 dates: 10 October 1991, 21 May 1992, 29 June 1992, 7 August 1992, 15 September 1992, 17 October 1992, and 16 June 1993. The location of each patch was determined by measuring the distances between the centre of the patch and 2 reference bolts drilled into the rock beside the pool. The boundary of each patch was traced onto an acetate sheet and digitized by computer to determine the patch area. Due to heterogeneity of variance as determined by Cochran's $C$ test $(p<0.05)$, mean change in patch area was compared among pools for each interval between sampling dates using Welch's test. Patches which coalesced with other patches (increased in area by $>75 \%$ between sampling dates) and those which disappeared were excluded from the analysis for subsequent time intervals. New patches were selected to replace those which disappeared. Pools 1 and 5 were excluded from the analysis for the interval from October 1992 to June 1993 due to the small number of patches that were monitored. Mean change in patch area was also compared among 3 successive intervals (winter/summer seasons): October 1991-May 1992, May-October 1992, and October 1992-June 1993. Since the change in patch area differed significantly among pools within time intervals, separate comparisons were done for each pool across the 3 time intervals. Due to the disappearance of some patches and the exclusion of others which coalesced, few patches were monitored over all 3 time intervals. Consequently, mean change in patch area was compared between time intervals by paired $t$ tests.

The mean percentages of Mytilus patches in a pool which disappeared or coalesced with adjacent patches were compared among time intervals using 1-way ANOVA after arcsine transformation, if necessary, to remove heterogeneity of variance (Cochran's $C$ test, $p<0.05$ ). Comparisons were made among months for the summer and fall of 1992 (May-June, June-August, August-September, September-October 1992) and among seasons (October 1991-May 1992, May-October 1992, October-June 1993). Post hoc comparisons of means were done using the Student-Newman-Keuls (SNK) test $(\alpha=0.05)$.

The recolonization by Mytilus of areas from which mussel patches had been cleared was monitored on the same dates that patch areas were measured (see above). A cleared area was considered recolonized if mussels were found within $\sim 20 \mathrm{~cm}^{2}$ around the centre of the original patch.

Associated macroalgae and the size distributions of live and dead Mytilus were recorded in 5 randomly selected patches from each pool on 3 dates: 10 October 1991, 29 June 1992, and 17 October 1992. The patches were removed from the substratum with a putty knife and all mussels and algae collected and taken to the 
laboratory. Shell length (SL) of mussels in each patch was measured with vernier calipers (accuracy = $\pm 0.5 \mathrm{~mm}$ ). Live mussels, dead mussels with drill holes indicative of whelk predation, and dead non-drilled mussels were recorded separately.

External rings on the shell of Mytilus were counted under a dissecting microscope. The number of rings on eroded areas of the shells of the larger mussels was estimated by comparing them to the shells of smaller mussels (Seed 1969b). The number of annual rings on the shells was related to SL by non-linear regression based on a sample of 578 mussels, ranging from 0.5 to $70.5 \mathrm{~mm}$ SL, collected in June 1992.

Recruitment rate of Mytilus, estimated as the percentage of mussels $<2 \mathrm{~mm}$ SL, was compared among pools and dates using a 2-way ANOVA with date as a fixed factor with 3 levels and pool as a random factor with 5 levels. Post hoc comparisons of means were made using the SNK test.

Density and size distribution of the dogwhelk Nucella lapillus were measured for each pool on July 30 or August 7, 1992. In the 2 smallest pools (Pools 3 and 5), all whelks were counted and measured (SL, accuracy $= \pm 0.5 \mathrm{~mm}$ ), and their density was expressed in terms of the total surface area of the pool. (Pool surface area was estimated by subdividing each pool into triangles with a common apex, measuring the base and height of these triangles with a measuring tape to calculate their areas, and then summing the areas.) In the larger pools, whelks were counted and measured in ten $0.04 \mathrm{~m}^{2}$ quadrats. Mean size and density of whelks were each compared among pools using 1-way ANOVA.

The independence of mussel mortality, $\mathrm{SL}$, and sampling date was examined by 3-way contingency table analysis using a series of log-linear models (Fienberg 1970). A log-linear model fits the data well when the G-statistic is low and there is no significant difference between the model and the data. The full model with all three 2-way interactions and a 3-way interaction was not computed because it yields expected values equal to the observed values (Fienberg 1970). The best fit model was determined using the method of partitioning discussed by Fienberg (1970). The significance of each interaction term was assessed by comparing the G-statistics of a hierarchy of all possible log-linear models, and by determining the difference in $G$-values between models which contained a particular interaction term and those which lacked it. The size distributions of dead mussels with drill holes and dead mussels without drill holes were each compared to the size distribution of live mussels for each pool (mussels from all patches were combined for each pool and sampling date). Mussels were grouped into 3 size classes for these analyses:
$<5,5-10$, and $10-25 \mathrm{~mm} \mathrm{SL}$. No dead mussels $>25 \mathrm{~mm}$ SL were found. In Pool 4, only 2 dead mussels $>10 \mathrm{~mm}$ SL were found and this size class was not included in the analysis. Pool 5 was excluded from the analysis due to low numbers of dead mussels.

\section{RESULTS}

\section{Spatial distribution of patches and association with macroalgae}

Mytilus patches were randomly distributed at each sampling scale with the exception of the $0.04 \mathrm{~m}^{2}$ scale in Pool 2 and the $0.25 \mathrm{~m}^{2}$ scale in Pools 1 and 2, where they were significantly aggregated (Table 2). Macroalgae occurred in 64 to $92 \%$ of the mussel patches that were destructively sampled (Table 3). Algal species most commonly associated with Mytilus patches were the filamentous green algae Cladophora sp. and Spongomorpha sp., the branched red alga Chondrus crispus, and the articulated coralline red alga Corallina officinalis. Other species included the sheet-like brown and green algae Scytosiphon lomentaria, Petalonia fascia, and Ulva lactuca, the filamentous red alga Bonnemaisonia hamifera, and the branched red alga Devaleraea ramentacea. These macroalgal species were rarely found on the open substratum between patches, which was encrusted by Hildenbrandia rubra, Ralfsia sp., or Phymatolithon sp. Mussels were usually attached to the algae; mussels $>2 \mathrm{~mm}$ were most commonly attached to coarsely branched macroalgae. Epizoic algae occurred only on the largest mussels ( $>40 \mathrm{~mm}$ ).

Table 2. Morisita's Index of Dispersion $\left(I_{\delta}\right)$ of Mytilus patches in 5 tidepools at Cranberry Cove, Nova Scotia p: probability of a random distribution $\left(I_{\delta}=1\right)_{i} \cdot{ }^{\cdot}$ a significant departure from a random distribution

\begin{tabular}{|ccccc|}
\hline Pool & $\begin{array}{c}\text { Quadrat } \\
\text { size }\left(\mathrm{m}^{2}\right)\end{array}$ & $\begin{array}{c}\text { Sample } \\
\text { size }(\mathrm{n})\end{array}$ & $I_{\delta}$ & $\begin{array}{c}\mathrm{p} \\
\left(\chi^{2}, \mathrm{n}-1 \mathrm{df}\right)\end{array}$ \\
\hline 1 & 0.04 & 20 & 1.12 & $0.05<\mathrm{p}<0.10$ \\
& 0.25 & 5 & 1.13 & $\mathrm{p}<0.005$. \\
2 & 0.01 & 7 & 0.86 & $\mathrm{p}>0.70$ \\
& 0.04 & 20 & 1.07 & $\mathrm{p}<0.025$ \\
& 0.25 & 5 & 1.07 & $\mathrm{p}<0.005$ \\
3 & 0.01 & 6 & 0.77 & $\mathrm{p}>0.80$ \\
& 0.04 & 6 & 1.04 & $0.10<\mathrm{p}<0.20$ \\
4 & 0.04 & 24 & 1.14 & $0.10<\mathrm{p}<0.20$ \\
& 0.25 & 6 & 1.05 & $0.20<\mathrm{p}<0.30$ \\
5 & 0.01 & 4 & 1.02 & $0.30<\mathrm{p}<0.40$ \\
& 0.04 & 12 & 1.00 & $0.40<\mathrm{p}<0.50$ \\
& 0.25 & 4 & 1.01 & $0.30<\mathrm{p}<0.40$ \\
\hline
\end{tabular}


Table 3. Mean percentage \pm SE of Mytilus patches which were associated with macroalgae in tidepools at Cranberry Cove, Nova Scotia. Sample size is 25 patches ( 5 from each of 5 pools) for each date

\begin{tabular}{|lccc|}
\hline Algal species & \multicolumn{3}{c|}{$\begin{array}{c}\text { Sampling date } \\
\text { June } 1992\end{array}$} \\
& October 1991 & October 1992 \\
\hline Chondrus crispus & $32.0 \pm 20.6$ & $31.0 \pm 8.7$ & $28.0 \pm 15.0$ \\
Corallina officinalis & $32.0 \pm 13.6$ & $54.0 \pm 13.3$ & $56.0 \pm 13.3$ \\
Spongomorpha sp. & $28.0 \pm 8.0$ & $66.0 \pm 15.4$ & $8.0 \pm 4.9$ \\
Cladophora sp. & $12.0 \pm 8.0$ & $26.0 \pm 8.7$ & $24.0 \pm 11.7$ \\
Bonnemaisonia hamifera & $12.0 \pm 12.0$ & $12.0 \pm 12.0$ & $8.0 \pm 8.0$ \\
Dumontia contorta & 0 & $20.0 \pm 20.0$ & 0 \\
Scytosiphon lomentaria & 0 & $54.0 \pm 10.7$ & 0 \\
Ulva lactuca & 0 & $4.0 \pm 4.0$ & 0 \\
Petalonia fascia & 0 & $8.0 \pm 4.9$ & 0 \\
Devaleraea ramentacea & 0 & 0 & $4.0 \pm 4.0$ \\
Ascophyllum nodosum & $4.0 \pm 4.0$ & 0 & 0 \\
Sp. not recorded & $8.0 \pm 4.9$ & $4.0 \pm 4.0$ & 0 \\
At least 1 sp. in patch & $76.0 \pm 7.5$ & $92.0 \pm 8.0$ & $64.0 \pm 9.8$ \\
\end{tabular}

between October 1992 and June 1993, particularly in Pool 1 where all patches were $<25 \mathrm{~cm}^{2}$ by June 1993.

The mean change in patch area (excluding patches which coalesced with other patches in a given time interval and patches which disappeared during the previous time interval) varied significantly among pools only between October 1991 and May 1992 (Welchs' Test, $F^{\prime \prime}{ }_{4,35.2}$ $=4.55, \mathrm{p}<0.01$ ) and between May and June $1992\left(F^{\prime \prime}{ }_{4.23 .3}=4.43, \mathrm{p}<0.01\right)$ (Fig. 2). Among-pool comparisons for all other intervals were nonsignificant $(p>0.10)$. Mean changes in patch area between intervals (winter/summer seasons) also were not significant for all pools ( $p>0.05$ ) (Fig. 2).

The rate of patch coalescence decreased significantly among months from spring to fall $1992\left(F_{3,16}=8.12, p=0.002\right)$ (Fig. 3), and was significantly higher during May-October 1992 than during October 1992-June $1993\left(F_{2,12}=4.90, \mathrm{p}=\right.$ 0.028 ). The rate of patch disappearance was low (3 to $7 \%$ ) from spring to fall 1992 (Fig. 3) and did not differ significantly among months $\left(F_{3.16}=0.548, p=0.66\right)$ or seasons $\left(F_{2,12}=0.534, \mathrm{p}=0.60\right)$.
Mytilus patches ranged from 1 to $800 \mathrm{~cm}^{2}$ in area and the number of mussels in a patch ranged from 7 to 2946. Mussel patch size distributions remained fairly stable over time for most pools but differed among pools (Fig. 1). Many mussel patches decreased in size
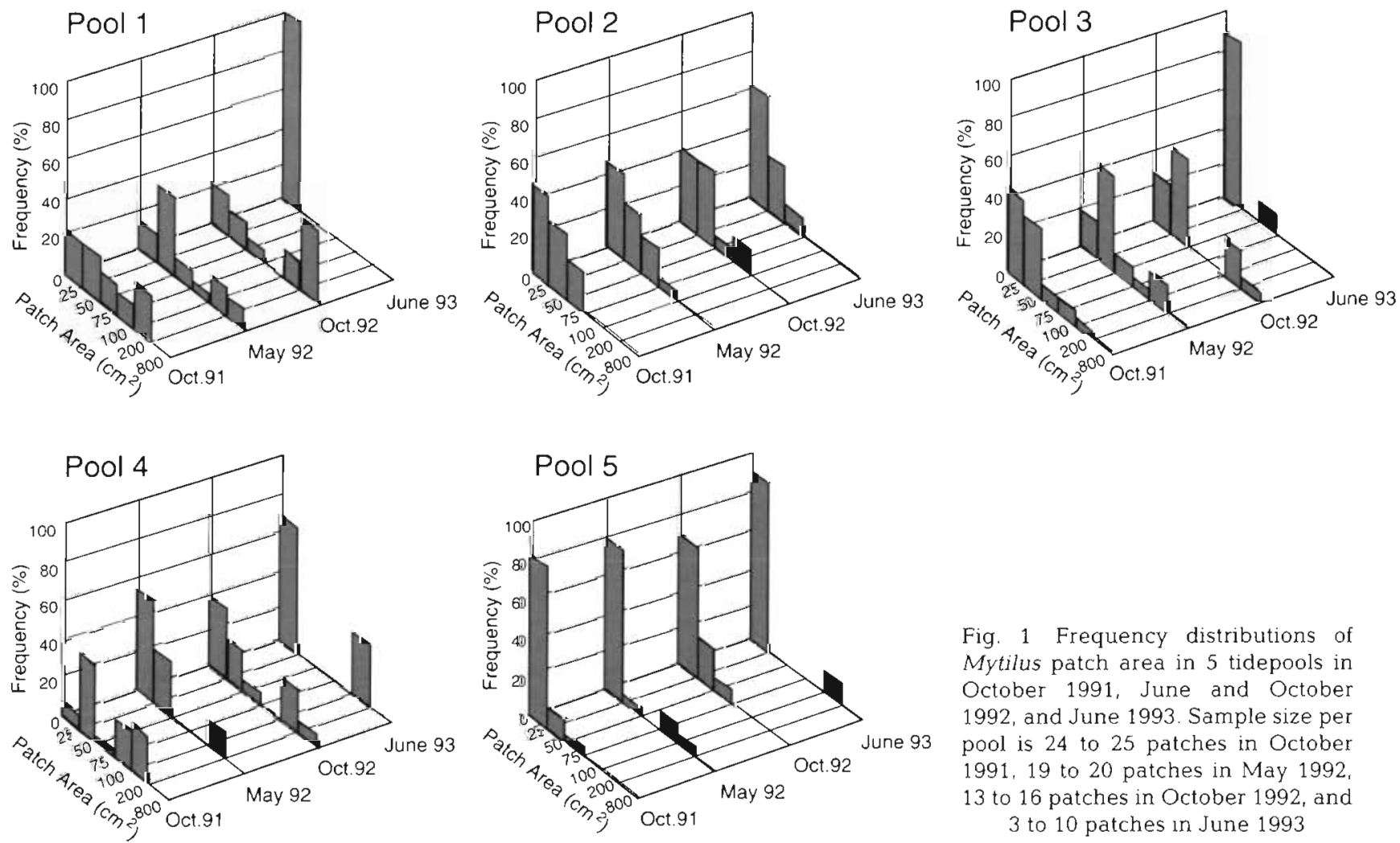

Fig. 1 Frequency distributions of Mytilus patch area in 5 tidepools in October 1991, June and October 1992, and June 1993. Sample size per pool is 24 to 25 patches in October 1991, 19 to 20 patches in May 1992, 13 to 16 patches in October 1992, and 3 to 10 patches in June 1993 


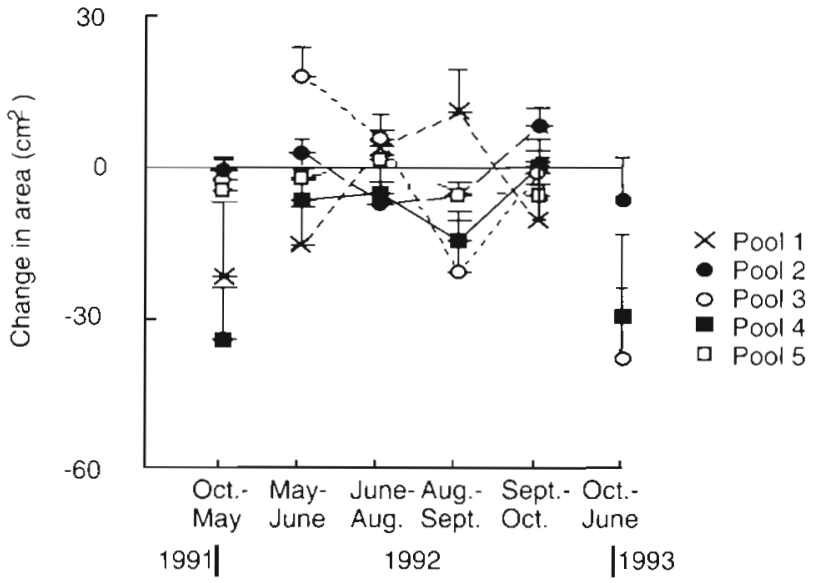

Fig. 2. Mean change $( \pm \mathrm{SE})$ in Mytilus patch area $\left(\mathrm{cm}^{2}\right)$ over 6 time intervals between October 1991 and June 1993 in each of 5 tidepools. Sample size per pool is 14 to 19 patches during October 1991-May 1992, 8 to 15 patches during May-June 1992, 4 to 12 patches during June-October 1992, and 4 to 6 patches during October 1992-June 1993

\section{Re-establishment of patches}

On average, recruitment of Mytilus occurred in $37 \%$ of the cleared areas during an 8 to 20 mo period after patch removal (i.e. by June 1993), and immigration from neighbouring patches occurred in $1 \%$ of the areas (Table 4 ). The percentage of the areas which were recolonized did not increase over time as many of the new colonists subsequently disappeared. The recolonization of many of the areas was preceded by colonization of macroalgae. Upright algae were associated with $53 \%$ (August 1992) to $100 \%$ (October 1992) of the patches of Mytilus recruits (Table 4). Corallina officinalis was the macroalgal species most often associated with these new patches; other species included Chondrus crispus, Scytosiphon lomentaria, Spongomorpha sp., and Cladophora sp.
Table 4. Mean percentage \pm SE of areas from which Mytilus patches were removed ( $n=25$ areas each in October 1991, June 1992, and October 1992) and which were recolonized by recruitment and immigration of mussels and the percentage of recruited patches associated with macroalgae. nm: not measured; $\mathrm{Co}=$ Corallina officinalis, $\mathrm{Sp}=$ Spongomorpha $\mathrm{sp} ., \mathrm{Cl}=$ Cladophora $\mathrm{sp} ., \mathrm{Sc}=$ Scytosiphon lomentaria, $\mathrm{Ch}=$ Chondrus crispus

\begin{tabular}{|lccccl|}
\hline Date & $\begin{array}{c}\text { Sample } \\
\text { size }\end{array}$ & $\begin{array}{c}\text { Mean percentage } \\
\text { of areas recolonized }\end{array}$ & $\begin{array}{c}\text { Percentage of } \\
\text { recolonized } \\
\text { areas with } \\
\text { algae }\end{array}$ & Algal species \\
\hline Recruitment Immigration & $4 \pm 4$ & 78 & $\mathrm{Co}, \mathrm{Sp}, \mathrm{Cl}$ \\
Juy 1992 & 25 & $36 \pm 12$ & $4 \pm 4$ & $\mathrm{Co}, \mathrm{Sc}, \mathrm{Ch}$ \\
August & 25 & $36 \pm 10$ & $4 \pm 4$ & 67 & $\mathrm{Co}, \mathrm{Sp}, \mathrm{Co}, \mathrm{Ch}$ \\
September & 50 & $36 \pm 8$ & $4 \pm 3$ & 53 & $\mathrm{~nm}$ \\
October & 50 & $10 \pm 3$ & $6 \pm 4$ & 100 & $\mathrm{Co}, \mathrm{Ch}$ \\
June 1993 & 75 & $37 \pm 6$ & $1 \pm 1$ & 65 & $\mathrm{Sp}, \mathrm{Sc}, \mathrm{Cl}, \mathrm{Co}$ \\
\hline
\end{tabular}

Fig. 3. Mean \pm SE percentage of (A) coalescence and (B) disappearance of Mytilus patches between October 1991 and June 1993 in 5 tidepools. Bars above (A) indicate the results of SNK multiple comparisons among months
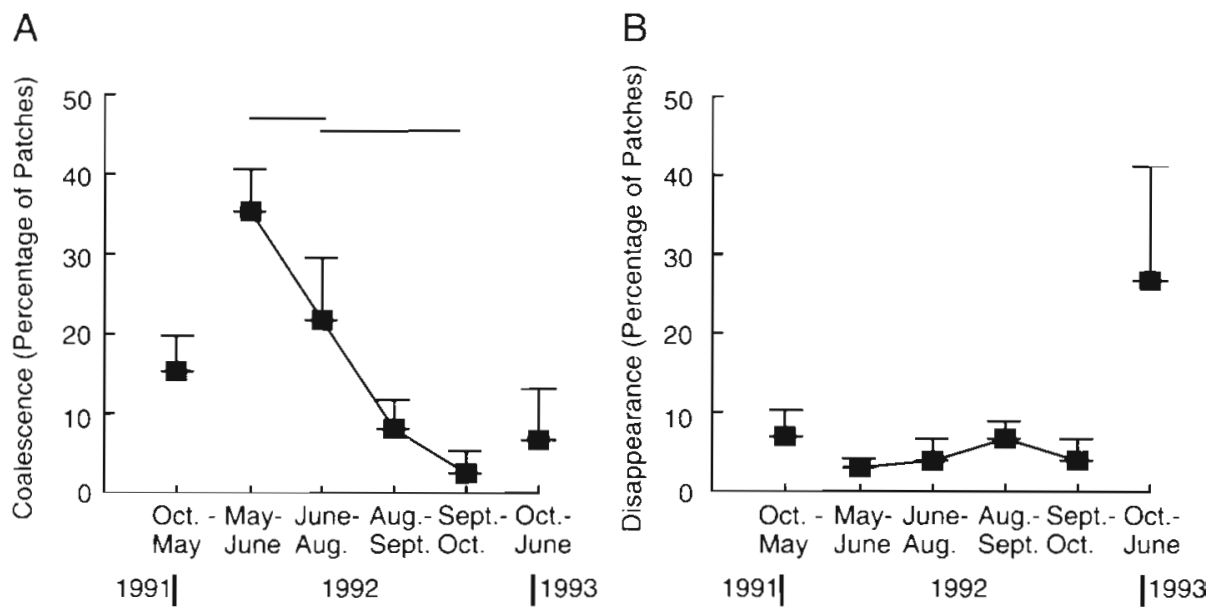

Size distributions of Mytilus in patches were highly skewed in all pools and on all sampling dates with a modal size class of $0-5 \mathrm{~mm}$ SL and few mussels $>20 \mathrm{~mm}$ SL (Fig. 4). Large mussels $>40 \mathrm{~mm}$ SL were rare.

The number of external rings on the shell (R) was exponentially related to shell length (Fig. 5) as given by the regression equation:

$$
\begin{gathered}
\mathrm{R}=-0.777+1.043 \times \mathrm{SL}(\mathrm{mm})^{0.686} \\
\left(\mathrm{r}^{2}=0.915\right) .
\end{gathered}
$$

Assuming the rings are annual (see Seed 1976, Seed \& Richardson 1990), this equation predicts that mussels in 
October 1991
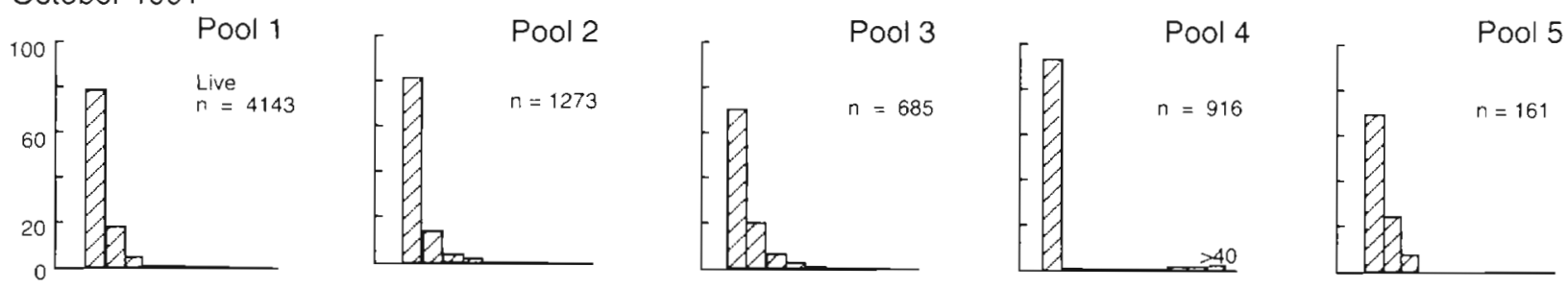

June 1992
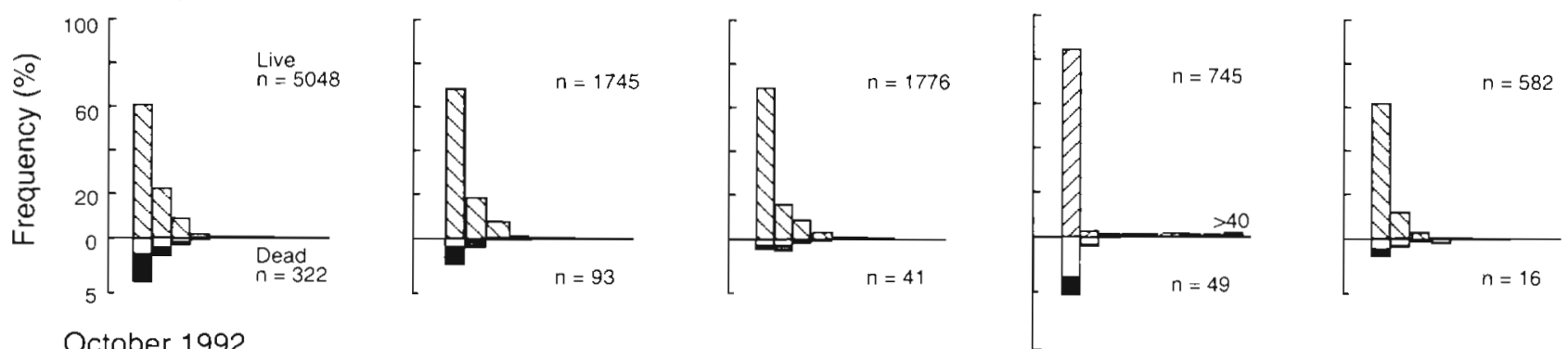

October 1992
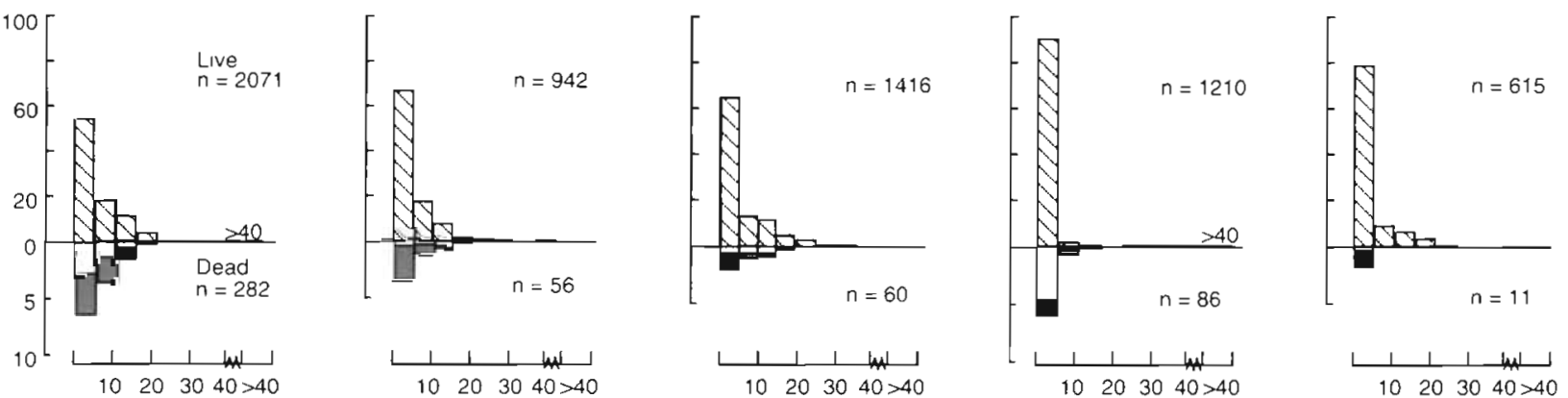

\section{Shell Length $(\mathrm{mm})$}

Fig. 4. Mytilus trossulus and $M$. edulis. Size-frequency distributions of live and dead drilled and dead non-drilled mussels in each of 5 tidepools in October 1991 and June and October 1992. Dead mussels were not recorded in October 1991

Q Live

Dead, drilled

Dead, non-drillled the modal size class $(0-5 \mathrm{~mm})$ were $<3$ yr old and that most of the population (i.e. those $<20 \mathrm{~mm}$ ) were $<7 \mathrm{yr}$ old (Fig. 5). The few large mussels ( $>40 \mathrm{~mm}$ ) were estimated to be 13 to 20 yr old.

\section{Recruitment}

There was a significant interaction between the effects of sampling date and pool on the percentage of new recruits of Mytilus $\left(F_{8,57}=2.57, p=0.018\right.$ ) (Fig. 6). The percentage of new recruits differed among dates in only 1 pool (Pool 5) where it was higher in October 1992 than in October 1991 (SNK test, $\mathrm{p}<0.05$ ).

\section{Mortality}

With the exception of Pool 1 in October 1992, <10\% of Mytilus in patches sampled in June 1992 and Octo-

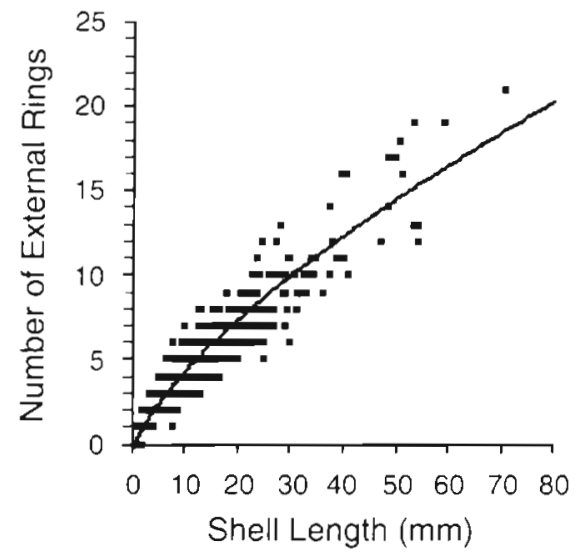

Fig. 5. Mytilus trossulus and M. edulis. Relationship between the number of external rings and shell length of mussels $(\mathrm{mm})$ in tidepools. Sample size $=578$ mussels 


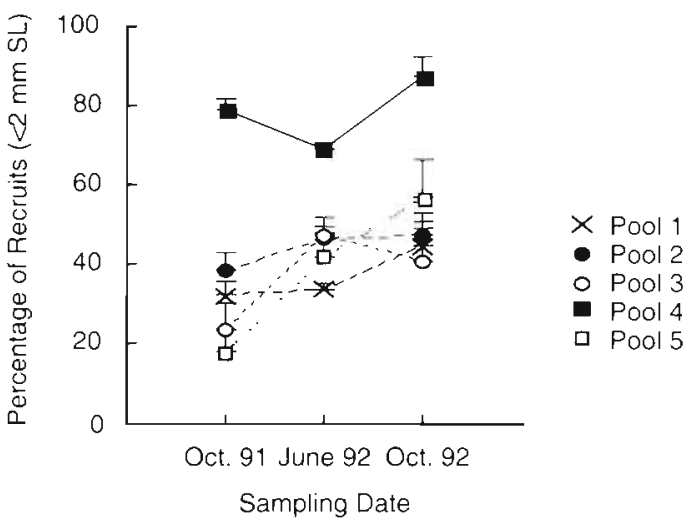

Fig. 6. Mytilus trossulus and $M$. edulis. Mean ( $\mathrm{SE}$ ) percentage of new recruits $(<2 \mathrm{~mm})$ in patches $(n=5)$ in each of 5 tidepools on 3 sampling dates

Table 5. Nucella lapillus. Shell length ( $\mathrm{mm}$ ) and mean density ( $\pm \mathrm{SE}$ ) (ind. $\mathrm{m}^{-2}$ ) of dogwhelks in each of 5 pools in August 1992. Sample size (n) in parentheses: for mean size $n=$ number of whelks collected in each pool; for density $\mathrm{n}=$ ten $0.04 \mathrm{~m}^{2}$ quadrats, except for Pools 3 and 5 where all whelks were counted

\begin{tabular}{|ccc|}
\hline Pool & Shell length & Density \\
\hline 1 & $13.4 \pm 2.4(8)$ & $20.0 \pm 5.5$ \\
2 & $10.0 \pm 2.6(7)$ & $17.5 \pm 7.7$ \\
3 & $11.7 \pm 2.5(8)$ & 10.8 \\
4 & $18.2 \pm 4.9(4)$ & $10.0 \pm 3.8$ \\
5 & $16.9 \pm 3.2(8)$ & 5.7 \\
\hline
\end{tabular}

ber 1992 were dead (Fig. 4). Dead mussels were primarily of the $0-5 \mathrm{~mm}$ modal size class, with the exception of Pool 3 in June 1992 when they were marginally more abundant in the $5-10 \mathrm{~mm}$ size class. Dead mussels $>25 \mathrm{~mm}$ SL were not found in the patches.

Whelk predation, as indicated by a drill hole in the mussel shell, accounted for $58.3 \pm 4.6 \%$ (mean $\pm \mathrm{SE}$ ) of Mytilus mortality in June 1992 and $40.0 \pm 9.2 \%$ of mor tality in October 1992 (Fig. 4). The density of whelks ranged from 5.7 to 20.0 individuals $\mathrm{m}^{-2}$ and their mean size ranged from 10.0 to $18.2 \mathrm{~mm}$ SL (Table 5). There were no significant differences among pools in whelk density $\left(F_{2,27}=0.646, \mathrm{p}=0.532\right)$ or size $\left(F_{4,30}=2.449\right.$, $\mathrm{p}=0.068$ ) nor was there a significant correlation between average whelk predation rate in June and October 1992 and whelk density in July/August 1992 $(\mathrm{r}=0.24, \mathrm{n}=5, \mathrm{p}=0.40)$.

The independence of mussel mortality due to whelk predation, sampling date, and SL was examined using 3-way contingency tables for each pool (Table 6a). In Pool 1, there was a 3 -way interaction between mussel size, date, and whelk induced mortality: the frequency of drilled mussels 5-10 $\mathrm{mm}$ and 10-25 mm was higher, and that of drilled mussels $<5 \mathrm{~mm}$ was lower, in June than in October 1992, while the converse pattern existed for live mussels. Only 2 -way interactions were significant for the other pools. The frequency of drilled mussels was higher in June than in October 1992 in Pool 2, but was independent of date in Pools 3 and 4. The size distributions of drilled mussels and live mus-

Table 6. Mytilus trossulus and $M$. edulis. Three-way contingency table analysis of the independence of mortality (M), sampling date (D), and size class (S) for (a) drilled dead mussels and (b) non-drilled dead mussels. G-statistics of all possible log-linear models are presented for each pool. B Best fit model. If no best model is indicated, the best fit model is a model containing all 2-way interactions and a 3 -way interaction

\begin{tabular}{|c|c|c|c|c|c|c|c|c|c|c|c|c|}
\hline \multirow[t]{2}{*}{ Models } & \multicolumn{3}{|c|}{ Pool 1} & \multicolumn{3}{|c|}{ Pool 2} & \multicolumn{3}{|c|}{ Pool 3} & \multicolumn{3}{|c|}{ Pool 4} \\
\hline & $G$ & $\mathrm{df}$ & $\mathrm{p}$ & $G$ & $\mathrm{df}$ & $\mathrm{p}$ & $G$ & $\mathrm{df}$ & $\mathrm{p}$ & $G$ & $\mathrm{df}$ & $\mathrm{p}$ \\
\hline \multicolumn{13}{|l|}{ (a) } \\
\hline$M+S+D$ & 45.4 & 7 & $<0.001$ & 21.9 & 7 & 0.003 & 58.9 & 7 & $<0.001$ & 19.8 & 4 & 0.001 \\
\hline$M+S+D+M \times D$ & 45.3 & 6 & $<0.001$ & 17.3 & 6 & 0.008 & 58.5 & 6 & $<0.001$ & 19.7 & 3 & $<0.001$ \\
\hline$M+S+D+M \times S$ & 41.0 & 5 & $<0.001$ & 15.4 & 5 & 0.009 & 31.3 & 5 & $<0.001$ & 9.8 & 3 & 0.021 \\
\hline$M+S+D+D \times S$ & 16.7 & 5 & 0.005 & 17.9 & 5 & 0.003 & 28.0 & 5 & $<0.001$ & 10.6 & 3 & 0.014 \\
\hline$M+S+D+D \times S+M \times S$ & 12.2 & 3 & 0.007 & 9.3 & 3 & 0.025 & 0.4 & 3 & $\cdot 0.947$ & 0.5 & 2 & $\cdot 0.774$ \\
\hline$M+S+D+D \times S+M \times D$ & 16.6 & 4 & 0.002 & 12.7 & 4 & 0.013 & 27.6 & 4 & $<0.001$ & 10.5 & 2 & 0.005 \\
\hline$M+S+D+M \times S+M \times D$ & 40.8 & 4 & $<0.001$ & 10.2 & 4 & 0.038 & 30.9 & 4 & $<0.001$ & 9.7 & 2 & 0.008 \\
\hline$M+S+D+M \times S+M \times D+D \times S$ & 12.2 & 2 & 0.002 & 5.1 & 2 & $\cdot 0.080$ & 0.2 & 2 & 0.919 & 0.2 & 1 & 0.674 \\
\hline \multicolumn{13}{|l|}{ (b) } \\
\hline$M+S+D$ & 109.6 & 7 & $<0.001$ & 15.1 & 7 & 0.035 & 55.0 & 7 & $<0.001$ & 23.1 & 4 & $<0.001$ \\
\hline$M+S+D+M \times D$ & 66.5 & 6 & $<0.001$ & 17.3 & 6 & $\cdot 0.314$ & 39.6 & 6 & $<0.001$ & 23.1 & 3 & $<0.001$ \\
\hline$M+S+D+M \times S$ & 106.6 & 5 & $<0.001$ & 15.4 & 5 & 0.026 & 47.6 & 5 & $<0.001$ & 8.5 & 3 & 0.036 \\
\hline$M+S+D+D \times S$ & 58.2 & 5 & $<0.001$ & 17.9 & 5 & 0.044 & 24.5 & 5 & $<0.001$ & 18.7 & 3 & $<0.001$ \\
\hline$M+S+D+D \times S+M \times S$ & 55.2 & 3 & $<0.001$ & 9.3 & 3 & 0.028 & 17.2 & 3 & 0.001 & 4.2 & 2 & $\cdot 0.125$ \\
\hline$M+S+D+D \times S+M \times D$ & 15.1 & 4 & 0.005 & 12.7 & 4 & 0.490 & 9.1 & 4 & 0.058 & 18.7 & 2 & $<0.001$ \\
\hline$M+S+D+M \times S+M \times D$ & 63.5 & 4 & $<0.001$ & 10.2 & 4 & 0.316 & 32.2 & 4 & $<0.001$ & 8.5 & 2 & 0.014 \\
\hline$M+S+D+M \times S+M \times D+D \times S$ & 10.4 & 2 & 0.005 & 5.1 & 2 & 0.682 & 1.7 & 2 & $\cdot 0.438$ & 4.1 & 1 & 0.042 \\
\hline
\end{tabular}


sels were significantly different in all pools. In comparison to the size distribution of live mussels, the frequency of drilled mussels $<5 \mathrm{~mm}$ was lower and the frequency of drilled mussels $5-10 \mathrm{~mm}$ was higher No clear pattern existed for mussels $10-25 \mathrm{~mm}$. There was an interaction between SL and date in all pools. There were no consistent patterns, except that mussels 10-25 mm were less frequent in June than October 1992.

The independence of other mortality (i.e. not due to whelks), sampling date, and Mytilus SL also was examined (Table 6b). As for drilled mussels, there was a similar 3-way interaction between $\mathrm{SL}$, date, and mortality in Pool 1, but only 2 -way interactions were significant for the other pools. The frequency of nondrilled dead mussels was higher in Pools 2 and 3 in October 1992 than in June 1992, while mortality and date were independent in Pool 4. SL and mortality not due to whelks were independent in Pool 2. In Pools 3 and 4 , however, the frequency of non-drilled dead mussels 5-10 mm was higher than that of live mussels while the frequency of non-drilled dead mussels 0-5 mm was less than that of live mussels. The frequency of non-drilled dead mussels $10-25 \mathrm{~mm}$ was greater than that of live mussels in Pool 3. There was an interaction between SL and date in Pools 3 and 4 . In Pool 3 the frequency of $0-5 \mathrm{~mm}$ and $5-10 \mathrm{~mm}$ mussels was greater while the frequency of $10-25 \mathrm{~mm}$ SL mussels was less in June 1992 than in October 1992. In Pool 4, the frequency of mussels $0-5 \mathrm{~mm}$ was lower and the frequency of mussels $5-10 \mathrm{~mm}$ was higher in June than in October 1992.

\section{DISCUSSION}

\section{Patch distribution and dynamics}

Mytilus patches tended to be associated with macroalgae, particularly filamentous green algae (Cladophora sp. and Spongomorpha sp.) or more coarsely branched red algae (Corallina officinalis and Chondrus crispus). Mussels were rarely attached to the seasonal sheet-like algae (Scytosiphon lomentaria, Petalonia fascia, Ulva lactuca). In Britain, western North America, and Japan, juveniles of Mytilus edulis have also been reported attached to filamentous algae, particularly red algae (De Blok \& Geelen 1958, Bayne 1964, Seed 1969a, Suchanek 1978, Tsuchiya \& Nishihira 1985, 1986, King et al. 1989). The random or aggregated distribution of Mytilus patches within pools may be partly dependent on the distribution of macroalgae, as many of the mussels appear to have settled on or around algae. The mussel patches may also enhance the recruitment of macroalgae by providing protection from grazers

Changes in Mytilus patch area varied markedly among patches within a pool and among pools. The lack of significant differences in change in patch size among pools after June 1992 may be partly due to smaller sample sizes (and lower power to detect differences) as patches were removed by destructive sampling and patches which coalesced or disappeared were excluded from the analysis. During the study, individual patches were dynamic, but no significant differences in mean change in patch area between time intervals were detected for any of the pools. There appeared to be no temporal trend in coalescence or disappearance of the patches.

The formation of gaps in mussel beds on emergent substrata has been attributed to wave action, particularly during winter storms (Dayton 1971, Paine \& Levin 1981). Denny (1987) has calculated that fluid dynamic lift forces caused by breaking waves can be large enough to remove mussels from beds on emergent substrata, initiating patch formation. Mussels are more susceptible to dislodgement by waves if they 'hummock' to form a mat several individuals thick since the mussels in the centre of the hummock lose contact with the substratum (Seed 1969a, Dayton 1971). In Pool 1, some of the patches which were missing in October 1992 had begun to hummock in July and August 1992, suggesting that they may have been dislodged by wave action. However, we did not find an elevated rate of mussel patch disappearance during fall and winter, the most stormy seasons. During the winter of 1992-93, sea ice removed the macrobenthic community from much of the shoreline, including 2 of the pools monitored in this study (Pools 1 and 4). The rate of disappearance of Mytilus patches in these 2 pools was elevated, but rates of loss of mussels in the other pools were similar to summer rates.

Some recolonization by Mytilus of areas from which mussel patches were removed was observed within 8 to $20 \mathrm{mo}$. Except in a few instances where adjacent mussel patches expanded into the location, the recolonization was through primary and secondary settlement. In many cases, newly recruited mussels were associated with algae that had also colonized these locations.

\section{Recruitment}

The size distributions of Mytilus in the pools were skewed, consisting primarily of mussels $<5 \mathrm{~mm} \mathrm{SL}$. A highly skewed distribution is characteristic of intertidal populations of Mytilus and has been attributed to variable individual growth rates and a prolonged recruit- 
ment period (Seed 1976). The percentage of new recruits in the mussel patches varied among pools and dates. Similarly, studies in New England have found large spatial and temporal variability in the recruitment of $M$. edulis on emergent substrata of rocky shores (Menge 1991, Petraitis 1991).

\section{Growth}

External rings were used to estimate the growth rate of Mytilus. Annual periodicity of ring formation has been confirmed for some Mytilus populations and rejected for others (for review see Seed 1976). Rings are caused by periods of suspended growth and are most likely to be formed annually in temperate areas where shell growth is greatly decreased or suspended in winter due to low temperatures (Seed 1976). Based on external ring analysis, Mytilus in tidepools at Cranberry Cove appear to be slow growing, reaching a length of $30 \mathrm{~mm}$ in $\sim 10 \mathrm{yr}$. In contrast, Mossop (1921) found that $M$. edulis in tidepools in St. Andrews, New Brunswick, grew $\sim 4 \mathrm{~mm}$ in $2 \mathrm{mo}$. However, her experiment was conducted with smaller aggregations with less potential for intraspecific competition than those monitored in our study. The growth rate of mussels $<10 \mathrm{~mm}$ SL in our pools was slower than that of larger mussels. This may be due to stronger effects of interference by neighbouring conspecifics on the growth rate of small compared to large mussels (Fréchette et al. 1992).

The growth rate of mussels in tidepools appears to be less than that of mussels on emergent substrata in several locations. Gardner \& Thomas (1987), working in the Bay of Fundy, Canada, and Bayne \& Worrall (1980), in southern England, obtained growth estimates of Mytilus edulis of $-30 \mathrm{~mm}$ in $3.5 \mathrm{yr}$. However, Seed (1969b) reported that some mussels in the mid intertidal zone in Yorkshire, England, grow to $30 \mathrm{~mm}$ SL in $\sim 10 \mathrm{yr}$, although the majority of the mussels are more slow growing. More rapid growth on emergent substrata may be related to a reduced metabolic rate during exposure to air (Widdows et al. 1979, Clarke \& Griffiths 1990).

\section{Mortality}

The dogwhelk Nucella lapillus is the major predator of Mytilus in tidepools in Nova Scotia (see also Minchinton 1989). Crabs (Carcinus maenas and Cancer irroratus) and starfish (Asterias vulgaris) were only occasionally found in the pools at low tide. Previous studies have demonstrated a direct relationship between size of $N$. lapillus and preferred prey size such that adult whelks (20 to $30 \mathrm{~mm} \mathrm{SL}$ ) prefer mussels 10 to $30 \mathrm{~mm} \mathrm{SL}$ (Largen 1967, Bayne \& Scullard 1978, Hughes \& Dunkin 1984, Hughes \& Burrows 1990, 1991). The mussel size class preferentially drilled in this study, 5-10 mm $\mathrm{SL}$, is smaller than that reported in other studies. This may be due to the low numbers of large mussels in patches or to the small sizes of whelks found in the pools. Juvenile whelks $(<5 \mathrm{~mm})$ were occasionally found within mussel patches that were destructively sampled (they were not detected when whelk densities were measured), and these may be the principal predators of mussels $<5 \mathrm{~mm}$. Largen (1967) noted that recently hatched whelks were capable of successfully drilling many prey species, including mussels $<20 \mathrm{~mm}$.

There were no consistent temporal patterns in whelk-induced mortality of Mytilus among pools. Both sampling dates (June and October) were during the period of the year when whelks are actively foraging in the pools. The frequency of non-drilled dead mussels was higher in October 1992 than in June 1992 in 2 of the 4 pools. This may reflect increased mortality during the summer. Temperatures in the pools may exceed $20^{\circ} \mathrm{C}$ during daytime low tides in July and August due to solar heating. Such high temperatures are energetically stressful for $M$. edulis, reducing scope for growth (Widdows 1978), and may result in increased mortality, particularly when they occur in conjunction with low food availability (Incze et al. 1980).

In comparison to the size distribution of live mussels, the frequency of non-drilled dead mussels $<5 \mathrm{~mm}$ was lower, and that of non-drilled dead mussels $5-10 \mathrm{~mm}$ was higher, in 3 of the 4 tidepools. Mussels $<5 \mathrm{~mm} \mathrm{SL}$ may be less vulnerable to mortality due to interspecific competition than mussels $5-10 \mathrm{~mm}$ because small mussels are more mobile. Young postlarval mussels migrate repeatedly (Maas Geesteranus 1942, Bayne 1964, Seed 1969a), probably drifting by means of a long mucous thread secreted for this purpose (Sigurdsson 1976, De Blok \& Tan-Maas 1977, Lane et al. 1985).

The patchy distribution of Mytilus in the tidepools is presumably maintained by a balance between processes which increase patch size (recruitment, immigration, growth of individuals) and those which decrease patch size (wave action, predation, and other sources of mortality). The absence of a temporal trend in patch size may reflect the protracted period of mussel recruitment and the lack of any clear seasonal trend in overall mortality.

Acknowledgements. We thank Allan Hennigar, Jodi Mailman, Toby Balch, and, particularly, Anna Metaxas for assistance in the field. This research was supported by a Natural Science and Engineering Research Council (NSERC) Undergraduate Student Research Award to H.L.H and an NSERC Research Grant to R.E.S. 


\section{LITERATURE CITED}

Bayne BL (1964) Primary and secondary settlement in Mytilus edulis L. (Mollusca). J Anim Ecol 33:513-523

Bayne BL, Scullard C (1978) Rates of feeding by Thais (Nucella) lapillus (L.). J exp mar Biol Ecol 32:113-129

Bayne BL, Worrall CM (1980) Growth and production of mussels Mytilus edulis from two populations. Mar Ecol Prog Ser 3:317-328

Burrows MT, Hughes RN (1991) Optimal foraging decisions by dogwhelks. Nucella lapillus (L.): influences of mortality risk and rate-constrained digestion. Funct Ecol 5:461-475

Clarke BC, Griffiths CL (1990) Ecological energetics of mussels Choromytilus meridionalis under simulated intertidal rock pool conditions. J exp mar Biol Ecol 137:63-77

Dayton PK (1971) Competition, disturbance, and community organization: the provision and subsequent utilization of space in a rocky intertidal community. Ecol Monogr 41 : 351-389

De Blok JW, Geelen HJFM (1958) The substratum required for the settling of mussels (Mytilus edulis L.). Arch Neerl Zool 13(Suppl):446-460

De Blok JW, Tan-Maas M (1977) Function of byssus threads in young postlarval Mytilus. Nature 267:558

Denny MW (1987) Lift as a mechanism of patch initiation in mussels. J exp mar Biol Ecol 113:231-245

Dethier MN (1984) Disturbance and recovery in intertidal pools: maintenance of mosaic patterns. Ecol Monogr 54:99-118

Elliott JM (1971) Some methods for the statistical analysis of benthic invertebrates. Freshwater Biological Association. Scientific Publication no. 25. Titus Wilson and Son, Ltd

Fienberg SE (1970) The analysis of multidimensional contingency tables. Ecology 51:419-433

Fréchette $M$, Aitken AE, Pagé L (1992) Interdependence of food land space limitation of a benthic suspension feeder consequences for self-thinning relationships. Mar Ecol Prog Ser 83:55-62

Gardner JPA, Thomas MLH (1987) Growth, mortality and production of organic matter by a rocky intertidal population of Mytilus edulis in the Quoddy Region of the Bay of Fundy. Mar Ecol Prog Ser 39:31-36

Goss-Custard S, Jones J, Kitching JA, Norton TA (1979) Tide pools of Carrigathora and Barloge Creek. Phil Trans R Soc London Ser B 287:1-44

Huggett J, Griffiths CL (1986) Some relationships between elevation, physico-chemical variables and biota of intertidal rock pools. Mar Ecol Prog Ser 29:189-197

Hughes RN, Burrows MT (1990) Energy maximization in the natural foraging behaviour of the dogwhelk, Nucella lapillus. In: Barnes M, Gibson RN (eds) Trophic relationships in the marine environment. 24th Eur Mar Biol Symp. Aberdeen University Press, Aberdeen, p 517-527

Hughes RN, Burrows MT \{1991\} Diet selection by dogwhelks in the field: an example of constrained optimization. Anim Behav 42:47-55

Hughes RN, Dunkin S de B (1984) Behavioural components of prey selection by dogwhelks Nucella lapillus (L.) feedng on mussels Mytilus edulis L., in the laboratory. J exp mar Biol Ecol 77:45-68

Incze LS, Lutz RA, Watling L (1980) Relationships between effects of environmental temperature and seston on growth and mortality of Mytilus edulis in a temperate northern estuary. Mar Biol 57:147-156

King PA, McGrath D, Gosling EH (1989) Reproduction and settlement of Mytilus edulis on an exposed rocky shore in Galway Bay, West Coast of Ireland. J mar biol Ass UK 69: $355-365$
Kitching JA, Sloane JF, Ebling FJ (1959) The ecology of Lough Ine VIII. Mussels and their predators. J Anim Ecol 28:331-341

Kooistra WHCF, Joosten AMT, van den Hoek C (1989) Zonation patterns in intertidal pools and their possible causes: a multivariate approach. Bot mar 32:9-26

Lane DJW, Beaumont AR, Hunter JR (1985) Byssus drifting and the drifting threads of the young post-larval mussel Mytilus edulis. Mar Biol 84:301-8

Largen MJ (1967) The diet of the dog-whelk, Nucella lapillus (Gastropoda Prosobranchia). J Zool Lond 151:123-127

Lawrence JM, McClintock JB (1987) Intertidal invertebrate and algal communities on the rocky shores of the Bay of Morbihan, Kerquelen (South Indian Ocean). PSZN I: Mar Ecol 8:207-220

Lubchenco J. Menge BA (1978) Community development and persistence in a low rocky intertidal zone. Ecol Monogr 48: $67-94$

Maas Geesteranus RA (1942) On the formation of banks by Mytilus edulis L. Arch Neerl Zool 6:283-325

McCook L, Chapman ARO (1991) Community succession following massive ice-scour on an exposed shore: effects of Fucus canopy algae and of mussels during late succession. $\mathrm{J}$ exp mar Biol Ecol 154:137-169

Menge BA (1976) Organization of the New England rocky intertidal community: role of predation, competition, and environmental heterogeneity. Ecol Monogr 46:355-393

Menge BA (1978) Predation intensity in a rocky intertidal community. Oecologia 34:1-16

Menge BA (1983) Components of predation intensity in the low zone of the New England rocky intertidal region. Oecologia 58:141-155

Menge BA (1991) Relative importance of recruitment and other causes of variation in rocky intertidal community structure J exp mar Biol Ecol 146:69-100

Minchinton TE (1989) Factors influencing settlement and survival of the bannacle Semibalanus balanoides (L.) in a developing rocky intertidal community in Nova Scotia, Canada. MSc thesis, Dalhousie University, Halifax

Mossop BKE (1921) A study of the sea mussel (Mytilus edulis Linn.). Contr Can Biol Fish 2:17-48

Paine RT (1974) Intertidal community structure: experimental studies on the relationship between a dominant competitor and its principal predator. Oecologia 15:93-120

Paine RT (1976) Size-limited predation: an observational and experimental approach with the Mytilus-Pisaster interaction. Ecology 57:858-873

Paine RT, Levin SA (1981) Intertidal landscapes: disturbance and the dynamics of pattern. Ecol Monogr 51:145-178

Pedersen EM (1991) Population genetics of Mytilus from a developing intertidal community in Nova Scotia, Canada. M.Sc thesis, Dalhousie University, Halifax

Petraitis PS (1990) Direct and indirect effects of predation, herbivory, and surface rugosity on mussel recruitment. Oecologia 83:405-413

Petraitis PS (1991) Recruitment of the mussel Mytilus edulis L on sheltered and exposed shores in Maıne, USA. $J \exp$ mar Biol Ecol 147:65-80

Robles C (1987) Predator foraging characteristics and prey population structure on a sheltered shore. Ecology 68: $1502-1514$

Seed R (1969a) The ecology of Mytilus edulis L. (Lamellibranchiata) on exposed rocky shores. I. Breeding and settlement. Oecologia 3:277-316

Seed R (1969b) The ecology of Mytilus edulis L. (Lamellibranchiata) on exposed rocky shores. II. Growth and mortality. Oecologia 3:317-350 
Seed R (1976) Ecology. In: Bayne BL (ed) Marine mussels: their ecology and physiology. Cambridge University Press, Cambridge, p 13-65

Seed R, Richardson CA (1990) Mytilus growth and its environmental responsiveness. In: Stefano GB (ed) Neurobiology of Mytilus edulis. Manchester University Press, New York, p 1-37

Seed R, Suchanek TH (1992) Population and community ecology of Mytilus. In: Gosling EM (ed) The mussel Mytilus: ecology, physiology, genetics, and culture Elsevier, Amsterdam, p 87-169

Sigurdsson JB (1976) The dispersal of young post-larval bivalve molluscs by byssus threads. Nature $262: 386-387$

Stickle WB, Moore MN, Bayne BL (1985) Effects of temperature, salinity and aerial exposure on predation and lysosomal stability of the dogwhelk Thais (Nucella) lapillus (L.). $\mathrm{J}$ exp mar Biol Ecol 93:235-258

This article was presented by R. N. Hughes (Senior Editorial Advisor), Bangor, UK
Suchanek TH (1978) The ecology of Mytilus edulis L. in exposed rocky intertidal communities. $\mathrm{J}$ exp mar Biol Ecol 31:105-120

Tsuchiya M. Nishihira M (1985) Islands of Mytilus as a habitat for small intertidal animals: effect of island size on community structure. Mar Ecol Prog Ser 25:71-81

Tsuchiya M, Nishihira M (1986) Islands of Mytilus as a habltat for small intertidal animals: effect of Mytilus age structure on the species composition of the associated fauna and community organization. Mar Ecol Prog Ser $31: 171-178$

Widdows $J$ (1978) Physiological indices of stress in Mytilus edulis. J mar biol Ass UK 58:125-142

Widdows J, Bayne BL, Livingstone DR, Newell RIE, Donkin P (1979) Physiological and biochemical responses of bivalve molluscs to exposure to air. Comp Biochem Physiol 62A: 301-308

Manuscript first received: November 8,1994

Revised version accepted: March 14, 1995 